\title{
Viability of autogenous bone grafts obtained by using bone collectors: histological and microbiological study
}

\section{Viabilidade dos enxertos autógenos obtidos com a utilização de coletores para osso: estudo histológico e microbiológico}

\author{
Alberto Blay* \\ Samy Tunchel* \\ Wilson Roberto Sendyk**
}

\begin{abstract}
The use of autogenous bone grafts is considered to be the best choice for reconstructive surgery. In the periodontal literature, the utilization of osseous coagulum was suggested by the end of the sixties. The purpose of this study is to consider the use of bone collectors (bone traps) as an alternative method for obtaining material to fill small bone imperfections, such as fenestrations and dehiscences. Thirty samples were obtained from bone drilling during fixture installation in patients (13 men and 17 women, with an average age of 54 years) requiring treatment at the Department of Periodontology and Implant Dentistry, University of Santo Amaro. These samples were fixed in $10 \%$ neutral formaldehyde for 24 hours and subjected to histological preparation, in order to evaluate the presence of viable osteoblasts. In addition, the material was placed in a fluid thioglycolate medium and incubated for 24 hours at $36 \pm 1{ }^{\circ} \mathrm{C}$ in aerobiosis and anaerobiosis. Bacterial growth evaluation was made by using six different culture media (MacConkey agar, blood agar base, mannitol salt agar, Anaerokit LTD medium, Anaerokit LTD - bile medium, Anaerinsol). The results show that, if proper care is taken to prevent saliva contamination during the surgical procedure, this method of collecting autogenous bone may be useful in situations where small amounts of bone are required.
\end{abstract}

DESCRIPTORS: Dental implantation; Bone transplantation; Bone regeneration.

RESUMO: A utilização de enxertos autógenos é considerada a melhor opção nos tratamentos cirúrgicos de reconstrução óssea. Na literatura periodontal, a utilização de coágulo ósseo foi sugerida no final da década de 60. O objetivo deste estudo é considerar a utilização de coletores para osso como um método alternativo de se obter osso autógeno para preenchimento de defeitos ósseos como fenestrações e deiscências. Trinta amostras foram obtidas no processo de perfuração do tecido ósseo, durante a instalação de implantes em pacientes (13 homens e 17 mulheres, com média etária de 54 anos) que foram submetidos a tratamento na Disciplina de Periodontia e Implantodontia da Universidade de Santo Amaro. Essas amostras foram fixadas em solução de formol neutro a $10 \%$ por 24 horas para serem analisadas histologicamente com o intuito de avaliar a presença de osteoblastos viáveis. Além das amostras fixadas, também foram obtidos espécimens que foram incubados em aerobiose e em anaerobiose, em meio de tioglicolato por $24 \mathrm{~h}$ a $36 \pm 1{ }^{\circ} \mathrm{C}$. A avaliação do crescimento bacteriano foi feita através de seis meios seletivos de cultura (ágar MacConkey, ágar-sangue, ágar manitol, meio Anaerokit LTD, meio Anaerokit LTD - bile e Anaerinsol). Os resultados mostraram que, se forem tomados certos cuidados para prevenir a contaminação com saliva durante o procedimento cirúrgico, este método de coletar osso autógeno pode ser útil em situações em que pequenas quantidades de osso são necessárias.

DESCRITORES: Implante dentário; Transplante ósseo; Regeneração óssea.

\section{INTRODUCTION}

The loss of one or more dental elements not only harms the patient psychologically, but also causes an atrophic condition of the tooth supporting tissues. The highest rate of alveolar bone reabsorption occurs in the period between 6 months and 2 years after a tooth extraction ${ }^{7}$, and this fact is ex- tremely important, since it will affect the position and the angle of an implant $t^{1,16}$.

This may result in situations in which the implant, to be placed in a favorable functional and aesthetical position, contains parts of its surface clear of bone coverage, originating bone imperfections such as dehiscences and fenestrations $s^{3,4,6,7,10}$. These anatomic bone defects, which cause the ex-

*DDS, Assistant Professor; **PhD, Chairman - Department of Implantology and Periodontology, School of Dentistry, University of Santo Amaro. 
Blay A, Tunchel S, Sendyk WR. Viability of autogenous bone grafts obtained by using bone collectors: histological and microbiological study. Pesqui Odontol Bras 2003;17(3):234-40.

posure of parts of the implants, may impair bone integration within a short period, as well as cause related infection problems ${ }^{18}$.

Minimization of these problems requires preoperatory diagnostics in order to evaluate the quality and quantity of the bone host. Intra-oral bone mapping as well as X-ray techniques are mandatory for evaluating the conditions of the bone tissue that will receive the implants ${ }^{8,13,21}$. However, even after careful preliminary planning, small bone imperfections might occur, leading us to use some guided bone regeneration technique.

Considering autogenous bone grafts as the best choice for reconstruction surgery procedures ${ }^{15}$, we adopted a technique based on the use of bone collectors for obtaining autogenous bone material, which allowed us to fill small bone defects, such as fenestrations and dehiscences, without having to involve a second (intra-oral or extra-oral) surgical area for obtaining autogenous bone.

The purpose of this study is to evaluate the microbiological and histological viability of a bone tissue which, to date, has been disregarded in bone-integrated implant surgeries.

\section{MATERIALS AND METHODS Clinical procedure}

\section{Patient selection}

Thirty patients (13 men and 17 women, aged between 38 and 70, with an average age of 54 years), in good general health condition, were included in this study. They were all patients of the Department of Implantology and Periodontology, University of Santo Amaro, Brazil. Patient selection criteria for this study were established so as to include patients with loss of one or more dental

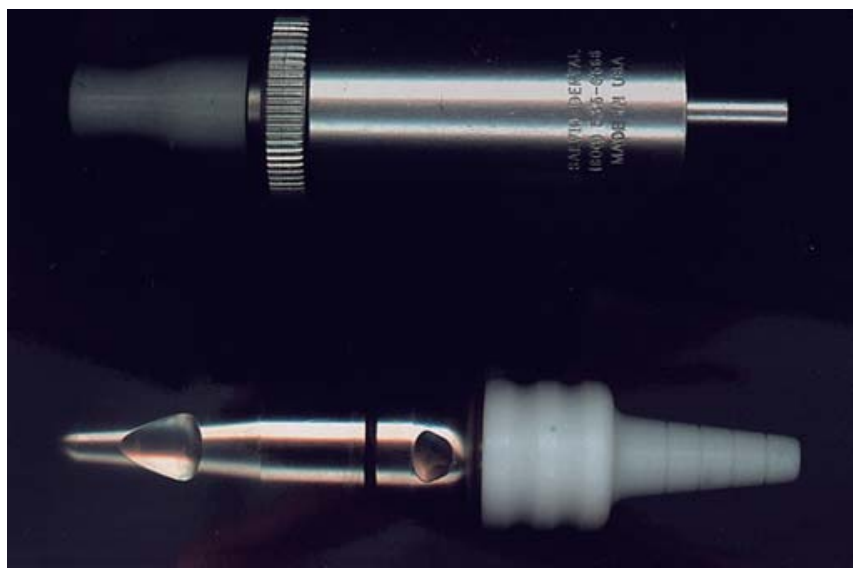

FIGURE 1 - Bone collectors used in the research. elements and with moderate alveolar atrophy. These characteristics were diagnosed in pre-operatory $\mathrm{X}$-ray examinations, such as panoramic radiography and computed tomography scans. An ethical committee evaluated and accepted the guidelines of the study. Before being included in the research all patients gave their informed consent.

\section{Surgical procedure}

All surgical procedures were performed under local anesthesia (with mepivacaine with $2 \%$ adrenaline - Scandicaine ${ }^{\circledR}$, Specialites Septodont, Saint-Maur-des-Fosses, France). Patients received antibiotic prophylaxis during 7 days (amoxine, Smithkline Beecham Brasil, Rio de Janeiro, Brazil, $1 \mathrm{~g}, 2$ hours before surgery and $500 \mathrm{mg}$ every 8 hours after surgery), and anti-inflammatory medication (sodium diclofenac, Novartis Biociências, São Paulo, Brazil) 50 mg every 12 hours, during 4 days.

Implants were installed following the protocol proposed by Branemark ${ }^{5}$ and Schulte ${ }^{19}$. Samples were obtained during the process of alveolar bone drilling, using two types of special bone collectors that can be described as autoclavable intermediate pieces with a collection chamber where the bone filters are located; these filters can be autoclavable or disposable (Osseous Coagulum Trap - Quality Aspirators; Duncaville, Texas, USA/Frios Bone Collector - Friadent, Mannheim, Germany). One of the extremities of this intermediate piece is connected to a high power suction pump and in the other extremity a surgical aspirator is inserted (Figures 1 and 2).

Precautions were taken in order to avoid contamination by saliva, which consisted in the mandatory utilization of two aspiration tips, one of them

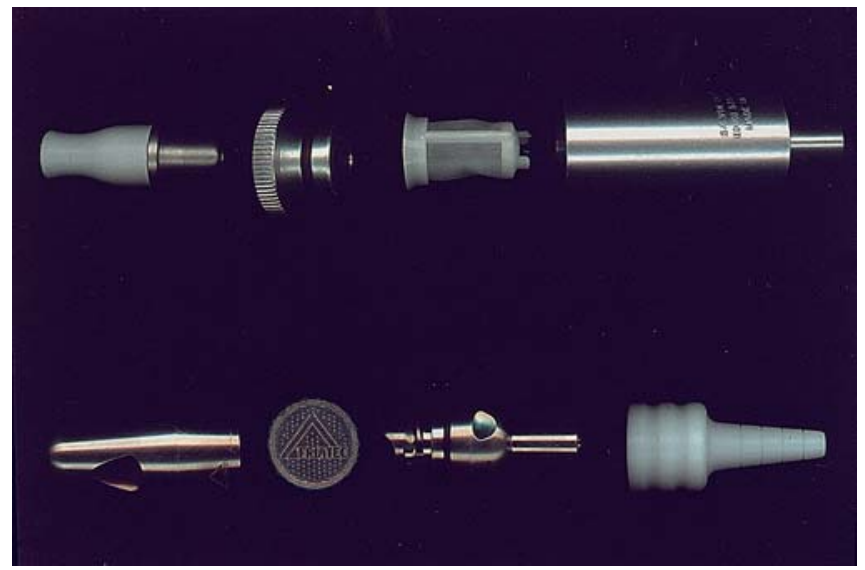

FIGURE 2 - Parts of the bone collectors before being mounted, showing the disposable filters. 
Blay A, Tunchel S, Sendyk WR. Viability of autogenous bone grafts obtained by using bone collectors: histological and microbiological study. Pesqui Odontol Bras 2003;17(3):234-40.

only for saliva aspiration and the other for the collector, the latter being kept at a distance of 5 to 10 millimeters from the area being prepared with the drills.

At 10-minute intervals, the collector's filter (Figure 3) was removed in order to avoid excessive dehydration of bone particles due to the action of the aspiration unit.

The collected tissue was placed in a glass vial containing sterile saline solution (Biossintética, São Paulo, Brazil) at room temperature and covered with a cap in order to minimize the risk of contamination. After fixture installation, the excess of saline solution was removed from the vial and the collected material was used to fill the bone defects (Figures 4 and 5).

At that moment, a small sample of the collected material was sent to microbiological and histological analysis. The flaps were closed with Donath

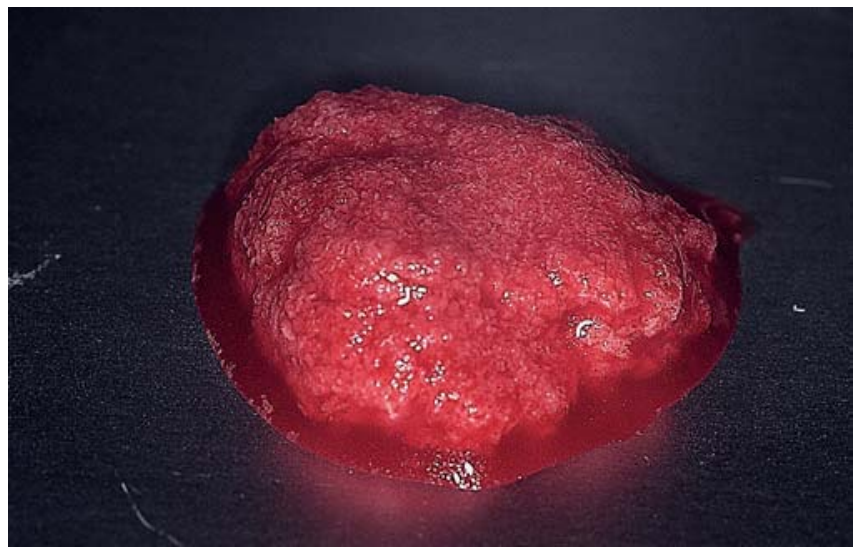

FIGURE 3 - Bone particles obtained from the filters.

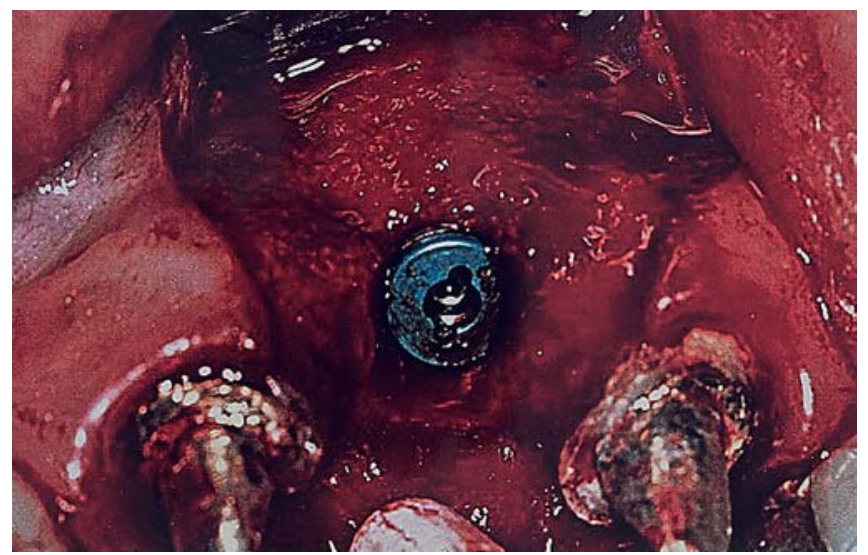

FIGURE 5 - The defect filled with autogenous bone from the collector. type surgical thread and simple individual sutures.

Mouth rinsing with a $0.12 \%$ solution of chlorexidine digluconate, twice a day, during two weeks after the surgery was prescribed.

Sutures were removed 7 days after surgery, and this patient was monitored at monthly appointments up to the moment of implant reopening surgery.

\section{Second surgical stage}

Reopening was performed 6 to 8 months after installation of the implants. Periapical X-rays were made at this treatment stage (Figure 6).

The areas were reopened by means of full-thickness flaps (Figure 7).

Biopsies were performed in the dehiscence area to provide small bone fragments for histological analysis. All cases showed bone growth over the

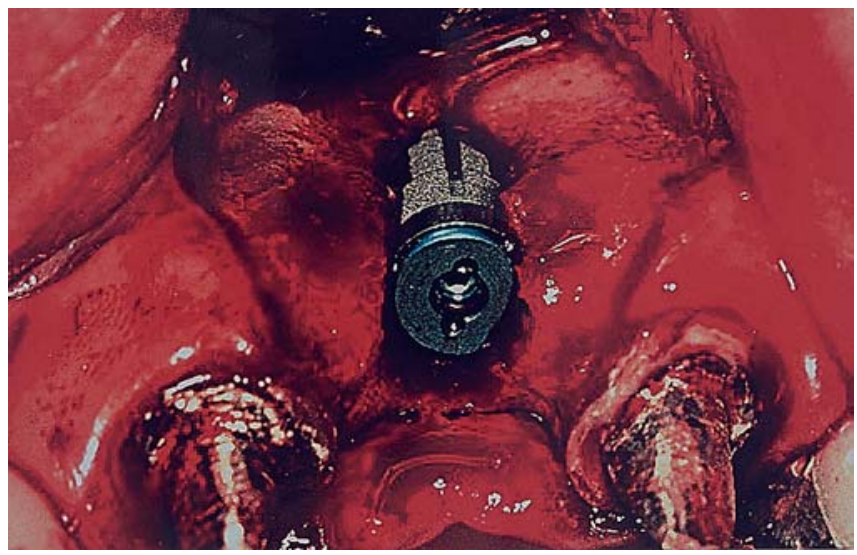

FIGURE 4 - Buccal dehicensce showing exposure of part of the implant at the time of installation.

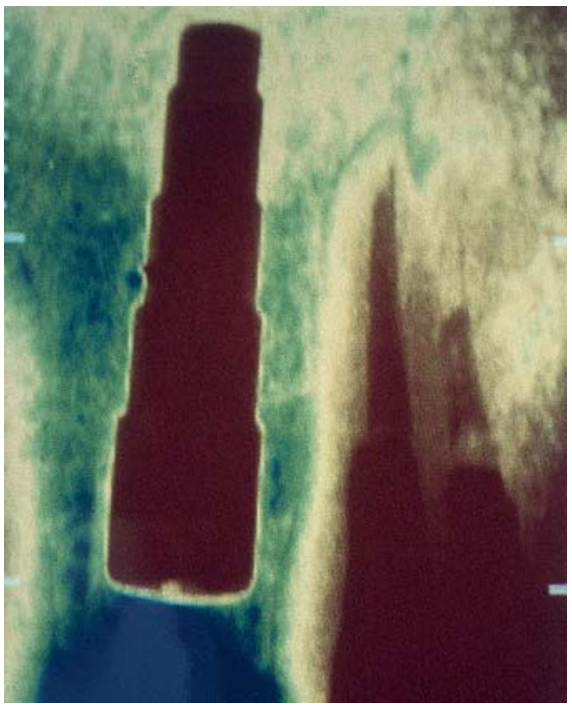

FIGURE 6 -

Periapical $\mathrm{X}$-rays were made 6 to 8 months after installation of the implants. 
Blay A, Tunchel S, Sendyk WR. Viability of autogenous bone grafts obtained by using bone collectors: histological and microbiological study. Pesqui Odontol Bras 2003;17(3):234-40.

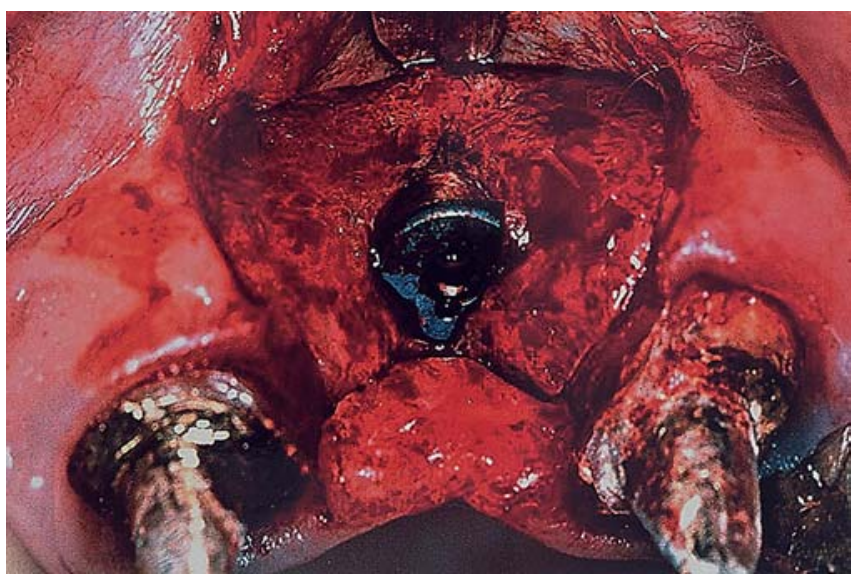

FIGURE 7 - Reopening at second stage surgery.

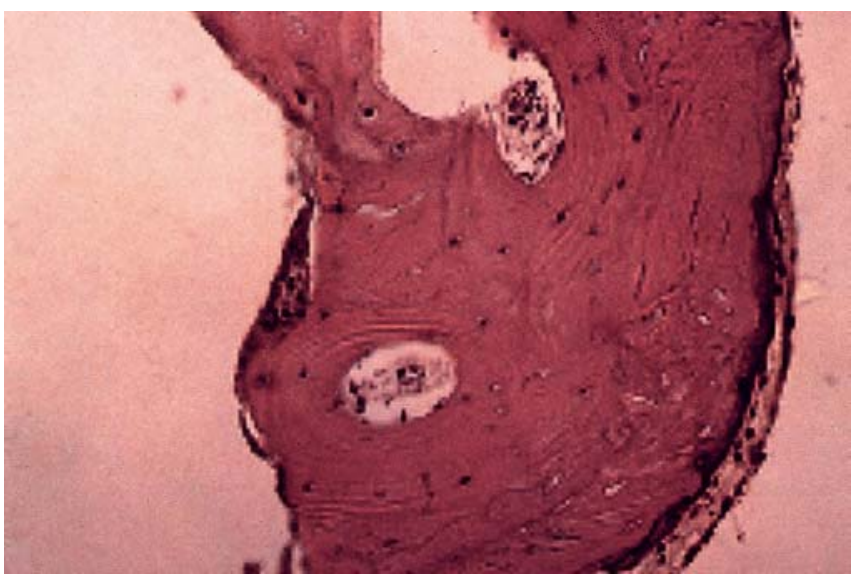

FIGURE 9 - At 6 months, haversian remodeling started within the compact cortical layer (acid fuchsin, $160 \mathrm{X}$ ).

cover screw, so we could take the biopsies without jeopardizing the bone around the implant.

\section{Microbiological analysis}

The samples were transported in a thioglycolate medium and incubated for 24 hours at a temperature of $36 \pm 1^{\circ} \mathrm{C}$ under aerobic and anaerobic conditions, in order to evaluate the presence of bacterial contamination. Evaluation of the colonies of the bacteria found was made using six different selective culture media (MacConkey agar, blood agar, mannitol agar, Anaerokit LTD medium, Anaerokit LTD - bile medium, Anaerinsol - Probac, São Paulo, Brazil).

\section{Histological analysis \\ Samples at fixture installation}

The samples collected at the time of implant installation in order to be processed histologically

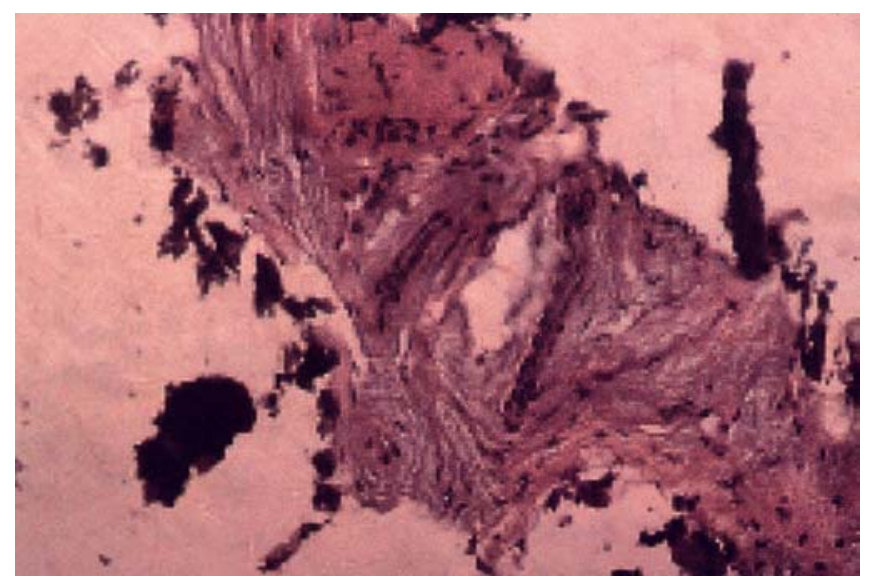

FIGURE 8 - Histological appearance of the bone obtained from the collector (acid fuchsin, $160 \mathrm{X}$ )

were fixed during 24 hours in a neutral formaldehyde solution at $10 \%$. Subsequently, they were decalcified in a vial containing 10\% EDTA during 4 weeks. The EDTA solution was changed every week in order to remove the calcium from the bone fragments through chelation.

After decalcification, the samples were embedded in paraffin, sliced with a microtome and stained with fuchsine, after which they were ready for microscopical analysis.

\section{RESULTS \\ Histological analysis \\ Samples at fixture installation}

Histological evaluation of the samples with an optical microscope showed that, even in a particulate state, the bone structure was well preserved (Figure 8), containing large numbers of osteocytes within the calcified matrix and suggesting that the viability of the bone tissue was maintained.

\section{Samples at second stage surgery}

All samples showed complete bone formation over the dehiscence defect. Samples at the second stage period showed a histologic bone structure similar to that of secondary bone. The Haversian system, typical osteocytes and a sharply defined layer of osteoblasts covering the mature bone fragment can be seen in Figure 9.

Some of the cells are surrounded by a newly formed bone matrix, indicating early stages of osteocyte maturation.

A basophilic line suggesting apositional growth, as well as the presence of osteo-progenitor or oste- 
Blay A, Tunchel S, Sendyk WR. Viability of autogenous bone grafts obtained by using bone collectors: histological and microbiological study. Pesqui Odontol Bras 2003;17(3):234-40.

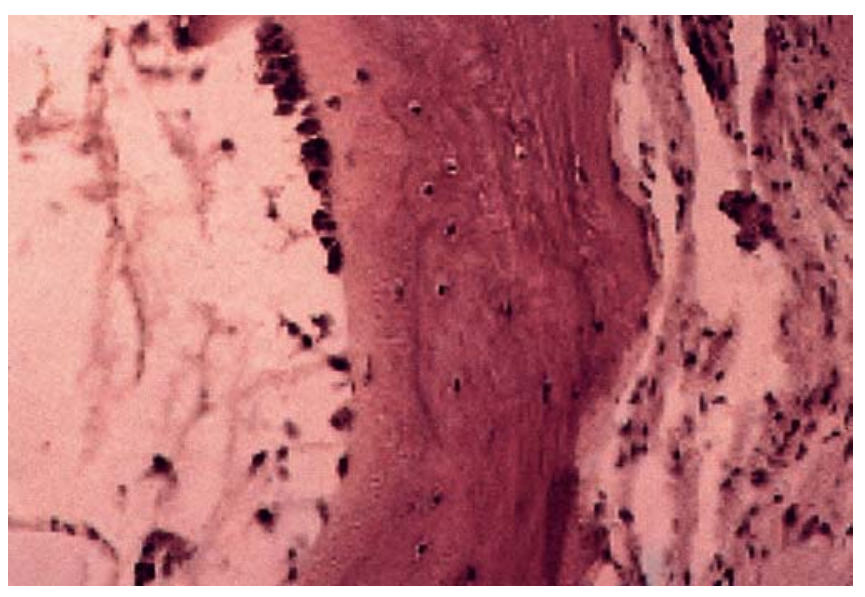

FIGURE 10 - Morphology of the bone after the healing process (6 months). Osteoblasts and osteocytes seams indicate bone apposition (acid fuchsin, $250 \mathrm{X}$ ).

ogenic cells (non-differentiated mesenchymal cells) can be observed in Figure 10.

\section{Microbiological analysis}

Under aerobic and anaerobic conditions, the presence of bacteria was clearly visible in the 30 samples submitted to microbiological analysis, when clouding was observed in the vials containing the samples and the transport medium thioglycolate, after an incubation period of 24 hours at a temperature of $36 \pm 1^{\circ} \mathrm{C}$.

The bacteria found in the samples were ascertained by including the samples, after an incubation period, in a thioglycolate medium, in six different selective culture media. Of these, three were selective media under aerobic conditions, and the other three were selective media under anaerobic conditions.

The blood agar selective medium, being an enriched medium, determined the presence of $\alpha$ and $\beta$ hemolytic streptococci, under aerobic conditions. The mannitol agar selective medium determined the presence of S. aureus and Staphylococcus negative coagulate under aerobic conditions.

The MacConkey agar selective medium determined the presence of Pseudomonae spp. and Citrobacterspp. The inclusion of these bacilli in another selective medium called IAL (Rugai medium, Probac, São Paulo, Brazil, modified by Pessoa and Sil$\mathrm{va}^{19}$ ) determined which of them fermented lactose and which of them did not. The identified lactose fermenting bacilli were Enterobacter and Citrobacter.

The selective media used for anaerobic conditions were Anaerokit and Anaerinsol, which deter-
TABLE 1 - Percentage of bacteria found in the 30 samples.

\begin{tabular}{l|c}
\hline \hline \multicolumn{1}{c|}{ Genera } & Percentage \\
\hline Streptococcus alpha hemolytic & 66.6 \\
\hline Staphylococcus aureus & 43.3 \\
\hline Streptococcus beta hemolytic & 36.6 \\
\hline Staphylococcus negative coagulate & 26.6 \\
\hline Pseudomonas spp. & 26.6 \\
\hline Citrobacter spp. & 16.6 \\
\hline \hline
\end{tabular}

mines the presence of Gram-negative bacilli, which produce black pigment. No other types of bacteria were found in this analysis.

In terms of genus, the percentages of the morphological types mentioned above are shown in Table 1 .

It is important to point out that the microbiological evaluation was qualitative and we did not count the number of bacterial colonies. It is known that most of the bacteria found in the samples are usually present in the normal microbiologic environment of the oral and/or oral-pharyngeal cavity.

\section{DISCUSSION}

Atrophy of the alveolar bone always presents difficulties for carrying out procedures which involve the placement of implants, and this problem has prompted the development of a number of techniques in order to obtain bone in sufficient quantity and quality. Utilization of autogenous bone in regeneration procedures, being a technique of proven success, is motivating a large number of researchers to continue developing procedures destined to overcome situations of bone atrophy ${ }^{2,11}$.

Utilization of autogenous bone is justified by the fact that this material has a high osteogenic potential in comparison with other types of materials. In addition, it has cells with bone induction capacity and does not produce immunological reaction $^{17}$.

For these reasons, we decided to investigate the method of obtaining autogenous bone tissue by means of collectors, a technique which is being used empirically by a large number of professionals and which, although apparently simple, requires a number of precautions in order to yield satisfactory results.

The use of bone collectors must be considered as an extremely conservative technique, since it 
Blay A, Tunchel S, Sendyk WR. Viability of autogenous bone grafts obtained by using bone collectors: histological and microbiological study. Pesqui Odontol Bras 2003;17(3):234-40.

eliminates the need of obtaining autogenous bone material from a second surgical area which always involves complex procedures. Furthermore, the bone material obtained by means of collectors is already in a particulate state, thus reducing operation time and the probability of contamination, since in this case there is no need to use bone crushers.

In our research project, all cases were carried out without membranes, and we noted that a bone graft made with a collector was efficient without having to use barriers. We think that in this way we have eliminated another risk factor, which is the use of membranes ${ }^{12,14,22}$.

As to the presence of microorganisms found during the collection process, we would like to point out that we found no Gram-negative anaerobic microorganisms, which are present in several forms of periodontal diseases and are known to produce enzymes capable of causing bone reabsorption. Furthermore, we must emphasize that the bacteria found in the samples did not show sufficient pathogenicity or virulence to harm the graft or the implant in any way. This is probably due to the systemic action of the broad spectrum antibiotics administrated to patients, or to the low virulence of the microorganisms found.

Therefore, we emphasize that it is mandatory to use two surgical aspirators, one of them only for saliva and another directly applied to the drilling site, collecting only cut bone and saline solution,

\section{REFERENCES}

1. Adell R, Lekholm U, Branemark PI. A 15-year-old study of osseointegrated implants in the treatment of the edentulous jaw. Int J Oral Surg 1981;6:387-96.

2. Adell R, Lekholm U, Grondahl K, Branemark PI, Lindstrom $\mathrm{J}$, Jacobson M. Reconstruction of severely resorbed edentulous maxillae using osseointegrated fixtures in immediate autogenous bone grafts. Int J Oral Maxillofac Implants 1990;5:233-46.

3. Albrektsson T. Osseointegrated titanium implants. Requirements for ensuring a long-lasting, direct bone anchorage in man. Acta Orthop Scand 1981;52:155-70.

4. Becker W, Becker BE. Guided tissue regeneration for implants placed into extraction sockets and for implant dehiscences: surgical techniques and case report. Int J Periodontics Restorative Dent 1990;10:376-91.

5. Branemark PI, Zarb GA, Albrektsson T. Tissue-integrated prostheses: osseointegration in clinical dentistry. Chicago: Quintessence; 1985.

6. Branemark PI. Intra-osseous anchorage of dental prostheses. I. Experimental studies. Scand J Plast Reconstr Surg 1969;3:81-100. thus reducing the risk of excessive bacterial contamination. We chose to close the suction unit of the bone collector at the moment we finished drilling, so as to avoid an excessive dehydration of the collected bone material, which could impair the viability of the bone inducing cells. At that moment the bone was removed from the collector and placed into a saline solution at room temperature.

From the results obtained we could conclude that, clinically as well as hystologically, the collection method was capable of preserving cells with bone induction capacity. Another positive factor is the utilization of autogenous bone tissue of membranous and not of endocondral origin, a material known to be more efficient because it has lower reabsorption levels ${ }^{23}$.

\section{CONCLUSIONS}

The surgery technique demonstrated here for obtaining particulate intra-oral autogenous bone material proved to be simple, efficient and safe.

During the bone collection procedure it is extremely important to avoid saliva contamination, which could cause failure of the graft and increase the risk of failure of the implant and of infection.

In spite of all precautions taken to prevent the presence of bacteria, this presence has been detected in all samples; the technique must therefore be improved in an attempt to eliminate any risk of contamination.

7. Buser D, Dula K, Belser U, Hirt HP, Berthold H. Localized ridge augmentation using guided bone regeneration. I. Surgical procedure in the maxilla. Int J Periodontics Restorative Dent 1993;13:29-45.

8. Buser D, Schoroeder A, Sutter F, Lang NP. The new concept of ITI hollow-cylinder and hollow-screw implants. Part 2: Clinical aspects, indications, and early clinical results. Int J Oral Maxillofac Implants 1988;3:173-81.

9. Carlsson GE, Persson G. Morphologic changes of the mandible after extraction and wearing of dentures. A longitudinal, clinical and X-ray cephalometric study covering 5 years. Odontol Revy 1967;18:27-54.

10. Dahlin C, Sennerby L, Kekholm U, Linde A, Nyman S. Generation of new bone around titanium implants using a membrane technique: an experimental study in rabbits. Int J Oral Maxillofac Implants 1989;4:19-25.

11. Jensen J, Simonsen EK, Sindet-Pedersen S. Reconstruction of the severely resorbed maxilla with bone grafting and osseointegrated implants: a preliminary report. J Oral Maxillofac Surg 1990;48:27-32. 
Blay A, Tunchel S, Sendyk WR. Viability of autogenous bone grafts obtained by using bone collectors: histological and microbiological study. Pesqui Odontol Bras 2003;17(3):234-40.

12. Jovanovic SA, Schenk RK, Orsini M, Kenney B. Supracrestal bone formation around dental implants: an experimental dog study. Int $\mathrm{J}$ Oral Maxillofac Implants 1995;10:23-31.

13. Kassebaum DK, Nummikoski PV, Triplett RG, Langlais RP. Cross-sectional radiography for implant site assessment. Oral Surg Oral Med Oral Pathol 1990;70:674-82.

14. Leghissa GC, Botticelli AR. Resistance to bacterial aggression involving exposed nonresorbable membranes in the oral cavity. Int J Oral Maxillofac Implants 1996;11:210-5.

15. Lundgren S, Moy P, Johanson C, Nilsson H. Augmentation of the maxillary sinus floor with particulated mandible: a histologic and histomorphometric study. Int J Oral Maxillofac Implants 1996;11:760-6.

16. Mecall RA, Rosenfeld AL. Influence of residual ridge resorption patterns on implant fixture placement and tooth position. Int J Periodontics Restorative Dent 1991;11:8-23.

17. Moy PK, Lundgren S, Holmes RE. Maxillary sinus augmentation: histomorphometric analysis of graft materials for maxillary sinus floor augmentation. J Oral Maxillofac Surg 1993;51:857-62.
18. Newman M, Flemmic T. Periodontal consideration of implants and implant associated microbiota. J Dent Educat 1988;52:737-44.

18. Pessoa GV, da Silva EA. A new medium for the rapid presumptive identification of enterobacteriae, aeromonas and vibrios. Ann Microbiol 1974;125A(3):341-7.

20. Schulte W, Heimke G. Das tübinger sofort-implantat. Quintessenz 1976;27:17-23.

21. Schwarz MS, Rothman SL, Rhodes ML, Chafetz N. Computed tomography: Part 1. Preoperative assessment of the mandible for endosseous implant surgery. Int J Oral Maxillofac Implants 1987;2:137-41.

22. Simion M, Scarano A, Gionso L, Piattelli A. Guided bone regeneration using resorbable and nonresorbable membranes: a comparative histologic study in humans. Int J Oral Maxillofac Implants 1995;10:23-30.

23. Sindet-Pedersen S, Enemark H. Reconstrution of alveolar clefts with mandibular or iliac crest bone grafts: a comparative study. J Oral Maxillofac Surg 1990;48:554-8.

Recebido para publicação em 23/05/02 Enviado para reformulação em 07/01/03 Aceito para publicação em 15/08/03 